\title{
Modelling distribution and potential overlap between Boreal Owl Aegolius funereus and Black Woodpecker Dryocopus martius: implications for management and monitoring plans
}

\author{
MATTIA BRAMBILLA, ENRICO BASSI, VALENTINA BERGERO, \\ FABIO CASALE, MARCO CHEMOLLO, RICCARDO FALCO, \\ VIOLETTA LONGONI, FABIO SAPORETTI, ENRICO VIGANÒ and \\ SEVERINO VITULANO
}

\begin{abstract}
Summary
Correlative species distribution models (SDMs) are increasingly widespread in the conservation literature. They can be used for a variety of purposes, including addressing practical conservation tasks on the basis of a spatially explicit assessment of environmental suitability for target taxa, which in turn allows for a transparent evaluation of needs and opportunities. Here we used the maximum entropy method (by means of the software MaxEnt) to model distribution of the rare Boreal Owl Aegolius funereus and the Black Woodpecker Dryocopus martius, which excavates the nest-holes used by the owl for breeding. We believe that monitoring surveys for Boreal Owl should consider areas suitable for both species as priority sites, whereas the provision of nestboxes for the owl may be particularly desirable in habitat patches that are suitable for that species but not for the keystone species whose nest-holes represent the usual nest site for the owl. Finally, areas suitable for both species can represent priority areas for the conservation of forest birds in the Alps, as both species have been reported as umbrella and/or keystone species. Our example provides a possible framework to model management and monitoring opportunities in other species or species pairs, but such an approach can be used to infer the need for particular management options when both limiting factors and species distribution can be spatially modelled, and also to model the areas where different target species are more likely to overlap and interact. The use of distribution models as tools to address practical conservation tasks should also be encouraged in order to accomplish practical tasks according to sound knowledge and transparent methods.
\end{abstract}

\section{Introduction}

Correlative species distribution models (SDMs) are increasingly widespread in the conservation literature (Jiménez-Valverde et al. 2008, Drew et al. 2011) and they are crucial to diverse applications in conservation science (Elith et al. 2006, Lawler et al. 2010). They are mostly based on the identification of species' ecological niches, on the basis of bioclimatic and other habitat features, but they can hardly take into account fine-scale factors, such as microhabitat or availability of specific resources, e.g. prey or breeding sites, which in birds can strongly affect distribution and local occurrence.

Several forest birds are secondary cavity breeders, i.e. they require pre-existing holes in trees for reproduction. Tree holes may be created by other species, such as woodpeckers, or by injuries 
to trees (Wesołowski 2007). The use of artificial sites, such as nest-boxes, is a common way of providing alternative or additional breeding opportunities (Newton 1994, Wesołowski 2007), and they have provided a basis for studies of e.g. population dynamics, evolution of life-history traits, quantitative genetics, natural and sexual selection (Møller 1989, Veen et al. 2001, Postma and van Noordwijk 2005, Both et al. 2006, Zingg et al. 2010).

Among secondary cavity breeders, some species nest mainly in holes excavated by one or a few species and their distribution is strongly affected by the distribution of the species providing suitable breeding cavities. In these cases, the species originally excavating the nest-holes is defined as a keystone species, as it provides key resources for other organisms in the same environment (Virkkala 2006). The habitat preferences and geographic distributions of keystone and "beneficiary" species often show a large overlap. In many cases, the use of artificial nests of comparable size to the holes created by the keystone species can increase the abundance of the secondary cavity breeder (Wesołowski 2007). Until now, nest-box provision has been driven by the expertise of local ornithologists and conservationists with the aim of increasing the population of a target species, or encouraging a species to settle. In some cases, nest-box provision has had negative effects on the population of target species by attracting birds to low quality habitats, leading to a decrease in reproductive output and even to eventual population extinction (Mänd et al. 2005, Klein et al. 2007).

Effective positioning of nest-boxes is desirable in any case, even apart from these extreme cases. In our opinion, nest-boxes may be more useful if placed in areas where i) the environment is suitable for the target species, and ii) nest-site cavities for the target species are unlikely to occur. Each one of these two statements each relies on an assumption: i) if habitat is not suitable, it could be inopportune to attract the target species by providing suitable artificial nests, and ii) if natural cavities occur, it could be detrimental to encourage a shift from natural to artificial sites, making the species tied to human provision of nesting support. On the other hand, if otherwise suitable habitats lack nesting holes, the use of nest-boxes might provide new opportunities for the target species.

A well known example of a dyad comprising a keystone and a beneficiary species is represented by Black Woodpecker Dryocopus martius and Boreal (or Tengmalm's) Owl Aegolius funereus. These are two largely resident or short-distance migrant species that are quite widespread in Central and Northern Europe, but become progressively rarer in southern countries. In Italy both species occur exclusively (Boreal Owl) or predominantly (Black Woodpecker) in the Alpine region. Boreal Owl nests almost exclusively in tree holes excavated by Black Woodpecker and secondarily in holes created by other woodpeckers, such as Grey-headed Picus canus and Green Woodpecker Picus viridis. Boreal Owl also quite frequently uses nest-boxes, which has permitted detailed studies of its ecology, ethology and population dynamics, especially in northern Europe (see e.g. Korpimaki 1985). In the Italian Alps, holes excavated by Black Woodpecker are by far the most frequently used nest sites by Boreal Owl, and the distribution of the latter closely mirrors the distribution of the former (Pedrini et al. 2005, Gustin et al. 2009). An effective strategy to increase the breeding opportunities and thus the population size of this regionally rare owl could be to provide nest-boxes in areas with forest habitats suitable for Boreal Owl but not hosting Black Woodpecker. In some areas of the Italian Alps, nest-boxes have been successfully installed for Boreal Owl (Mezzavilla and Lombardo 1997), but in some cases with low breeding success (see Brichetti and Fracasso 2006), and in the Spanish Pyrenees nest-boxes have also been installed to support a declining owl population (López et al. 2010).

In this work, we used SDMs to design monitoring and practical management for the regionally rare Boreal Owl. We made a spatially explicit assessment of the potential usefulness of a simple management option, the provision of artificial nests in order to maximize the conservation benefits for that species, and we identified priority areas for monitoring. We used SDMs to create a map of potential distribution for Boreal Owl then we modelled the distribution of Black Woodpecker. Finally, by combining the output of the two models, we identified areas suitable for both species and areas suitable for the owl but not for the woodpecker. In our opinion, the former should be regarded as priority sites for Boreal owl monitoring, whereas the latter should be regarded as 
preferred sites for providing nest-boxes, as such areas could potentially host owl breeding pairs according to their environmental traits, but are unlikely to provide nesting sites, given the likely absence of Black Woodpecker.

\section{Methods}

\section{Study area}

Our work took place in Lombardy, northern Italy $\left(23,870 \mathrm{~km}^{2}\right)$. Elevation ranges from a few meters above sea level near the eastern part of the Po plain, to 4,049 m (Mount Bernina). The region can be roughly divided into three geographical sectors: Alpine and pre-Alpine, occupying the northern part of the region; the Po river plain, in the centre (including the main towns), and the Apennine sector in the south-western corner of Lombardy.

Most of the study area has been strongly altered by human activities, with the exception of the Alpine area, and secondarily of the pre-Alpine and Apennine sectors. Alpine areas are dominated by coniferous and mixed woodlands, whereas pre-Alpine and Apennine sectors are mainly covered by broadleaved woodland.

\section{Fieldwork}

Boreal Owl and Black Woodpecker were surveyed during spring 2010 in the pre-Alpine and Alpine sectors. Additional field surveys in other areas (lowland, Apennines) did not result in any contact with the species. Some additional owl data collected in springs 2006-2009 were also used. For both species, we recorded occupied nests, spontaneous contacts (both visual and acoustic) and elicited responses to playback of broadcast song, a census technique relying on their high territoriality. All records of Boreal Owl were likely to be collected in areas without nest-boxes. When nests were found, other records from the same territory were discarded. In the case of multiple records likely from the same territories, we used the mid-point of territorial locations. Overall, we used 109 nest/territorial records for Black Woodpecker and 23 for Boreal Owl. The regional populations of the two species are estimated at 400-80o pairs for Black Woodpecker and 250-500 pairs for Boreal Owl (Gustin et al. 2009 and references therein).

\section{Modelling species distribution}

We utilized one of the most used (Elith et al. 2011) software programs for modelling species distribution using presence-only data, MaxEnt 3.3.3k (Phillips et al. 2006). Habitat factors used were land cover variables, derived from a detailed land cover map dated 2009 (DUSAF 3.0; Regione Lombardia/ERSAF), and a topographic variable, elevation, derived from a DTM of the region. A full list of environmental variables considered for model building is reported in Table $\mathrm{S}_{1}$ in the online supplementary material. Land cover variables were entered as the amount of 45 nonurban land cover types in a 1 x $1 \mathrm{~km}$ square, whereas elevation was the average value within the same squares; the cell size corresponded to the average size of breeding territories of Boreal Owl, and to the dimension of the core area within Black Woodpecker territories (Bocca et al. 2007). Fitting functions used for model building were linear, quadratic and hinge. Each model was replicated to times to assess model robustness and consistency among replicates. Both models were also built using all data as training data, and their output and threshold values were used as bases for analyses.

We considered as "important predictors" all those variables with percentage contribution higher than $5 \%$. Such variables were invariably also the ones with the highest values in jacknife analyses (details not shown). We used the respective "equal training sensitivity and specificity" (ETSS) calculated by MaxEnt as a cut-off for a binomial occurrence probability (O/I) (Bartel and Sexton 2009, Brambilla and Ficetola 2012, Brambilla et al. 2012). 


\section{Identifying priority areas for monitoring and for artificial nest provision}

Priority areas according to our initial premises were identified on GIS by combining the two distribution models. Areas identified for monitoring Boreal Owl are those which are likely to be occupied by both the study species. To identify priority areas for nest-boxes, we subtracted from the owl model all the cells depicted as suitable for the woodpecker. Then we selected the remaining cells classed as suitable for the owl. These cells (hereafter referred to as candidate cells) could be considered particularly suited for nest-boxes, as they are suitable for the owl, but are unlikely to host Black Woodpeckers or contain suitable nest-holes.

\section{Results}

Our two study species showed some shared and other mutually exclusive ecological traits (Table $I$ and online supplementary material). Elevation and coniferous woodland with medium or high tree density were among the most important factors affecting the distribution of both species. The response to coniferous woodland was positive and nearly linear for the woodpecker, whereas its effect on owl occurrence become much stronger for high coverage ( $\geq 80$ ha per $\mathrm{km}^{2}$ ). For elevation the effect was similar, with highest occurrence probability for both species around $1,300-1,400 \mathrm{~m}$, but with a much steeper decline in occurrence probability for the woodpecker for values above $1,500 \mathrm{~m}$. Occurrence probability for Boreal Owl was positively associated with the availability of at least to ha of permanent grasslands, whereas it was negatively affected by coppiced broadleaved woodland and shrubland, and weakly but positively affected by sparse vegetation (positive effect especially for low cover of this land cover type). Black Woodpecker occurrence was negatively affected by arable land. This means that many sites could be suitable for both species, while others would be suitable for just one of the two. Distribution maps confirmed this pattern: the predicted distributions are quite similar, but there are some areas suitable for only one species (Figures 1 and 2). Both models had a good discriminatory ability (AUC equal to $0.95 \pm$ 0.03 for Boreal Owl and $0.92 \pm 0.03$ for Black Woodpecker).

The reclassifying analysis based on the ETSS threshold identified 1,092 cells suitable for Boreal Owl and 1,531 for Black Woodpecker.

Of the cells suitable for the woodpecker, 725 were suitable for both species (two cells in the Apennines excluded; see below), and should be taken as priorities for Boreal Owl monitoring.

Subtracting cells suitable for the woodpecker from the cells depicted as suitable for the owl led to the identification of 367 candidate cells, within which nest-box provision for Boreal Owl should be

Table 1. MaxEnt models: most important variables (\% contribution higher than $5 \%$; value shown in brackets; for all other variables for both species, contribution lower or equal to $2.3 \%$ ). See supplementary material for further details.

\begin{tabular}{|c|c|c|}
\hline Variable & Aegolius funereus & Dryocopus martius \\
\hline $\begin{array}{l}\text { coniferous woodland } \\
\text { (medium or high tree density) }\end{array}$ & $\begin{array}{l}\text { positive especially when } \\
\text { cover } \geq 80 \%(41.7)\end{array}$ & positive (46.8) \\
\hline elevation & $\begin{array}{l}\text { higher occurrence probability } \\
\text { around } 1,300-1,400 \mathrm{~m}, \\
\text { then gradual } \\
\text { decline }(14.2)\end{array}$ & $\begin{array}{l}\text { higher occurrence } \\
\text { probability around } \\
\text { 1,300-1,400 m, then } \\
\text { steep decline (11.7) }\end{array}$ \\
\hline arable land & & negative (15.5) \\
\hline permanent grasslands & positive: at least 1o ha required (11.9) & \\
\hline $\begin{array}{l}\text { broadleaved woodland } \\
\text { (medium or high tree } \\
\text { density; coppiced) }\end{array}$ & negative $(9 \cdot 3)$ & \\
\hline shrubland & negative (6.5) & \\
\hline sparse vegetation & slightly positive $(5.7)$ & \\
\hline
\end{tabular}




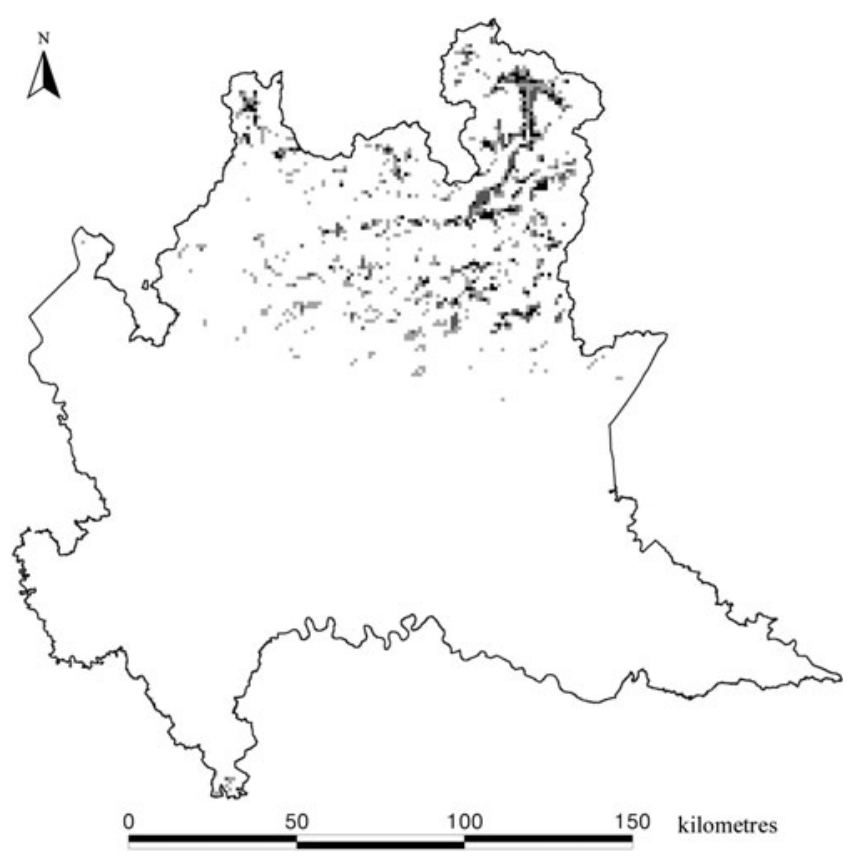

Figure 1. Suitable areas for Boreal Owl Aegolius funereus according to the MaxEnt model; the darkest the colour, the highest the occurrence probability.

particularly effective; obviously, the largest concentrations of candidate cells of high suitability indicated the most suitable areas for nest-box positioning (Figure 3). A few suitable cells in the Apennines (southern corner of the region) have been excluded from the set of potentially occupied sites (now or after nest-box positioning) for Boreal Owl, despite habitat structure and elevation being compatible with its ecological requirements, as these sites are outside the geographical range of the species in Lombardy.

\section{Discussion}

Basically, correlative SDMs assess relationships between species distribution data and environmental features to evaluate the suitability of a given area for that species. The models for both study species matched the anecdotal evidence available in the region and neighbouring areas, which suggests the same conditions depicted by models are preferred by the two species (Pedrini et al. 2005, Gustin et al. 2009). The models further highlight for Boreal Owl a positive effect of the availability of permanent grassland and a few areas with sparse vegetation, consistent with the hunting habits of the species and an avoidance of shrubland, already reported elsewhere (Cramp 1985). The negative effect of coppiced broadleaved woodland is not surprising, as this type of forest is poorly structured and characterised by mainly young trees, with a closed canopy (Cramp 1985).

The probability of presence provided by SDMs can be used for many purposes, including defining species' spatial occurrence (Graham et al. 2004, Brambilla et al. 2009), informing surveys (Raxworthy et al. 2003, Bourg et al. 2005), evaluating impacts of climate and habitat change (Thuiller et al. 2005, Brambilla et al. 2010, Fouquet et al. 2010, Elith et al. 2011), testing evolutionary hypotheses (Peterson et al. 1999, Graham et al. 2004), predicting species invasions (Roura-Pascual et al. 2004, Thuiller et al. 2005, Ficetola et al. 2007), informing conservation planning (Araújo and Williams 2000, Ferrier et al. 2002), predicting species abundance (VanDerWal et al. 2009) and seasonal shifts 


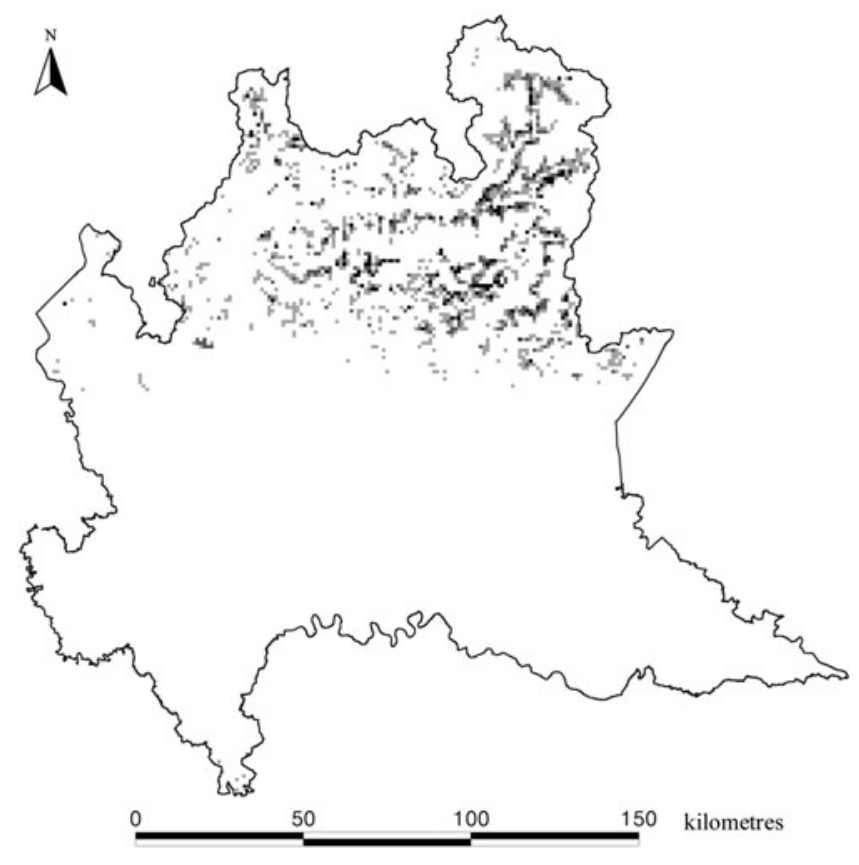

Figure 2. Suitable areas for Black Woodpecker Dryocopus martius according to the MaxEnt model; the darkest the colour, the highest the occurrence probability.

(Brambilla et al. 2012). In recent years, SDMs have become frequently utilized in conservation, and presence-only SDMs are becoming prevalent.

Here, we show how presence-only SDMs may also be used to address other practical conservation questions, such as effective monitoring plans and optimal nest-box provision. Although the use of cells necessarily introduces some approximation, it also shows the location of sites and their prioritisation and classification. Monitoring of Boreal Owl should consider areas suitable for both species as priority sites, as the areas unsuitable for the woodpecker are unlikely to host owls, because in the absence of alternative suitable nest-holes (e.g. nest-boxes) the owl cannot occupy them. On the other hand, until now provision of nest-boxes has been driven by expert opinion and empirical assessment of habitat suitability, by logistic constraints, or by study-design needs, whereas methods aimed at maximising their usefulness for conservation are rare (López et al. 2010). Our example provides a possible framework for identifying criteria and sites and for developing a spatially explicit assessment of the usefulness of nest-boxes for the conservation of a species. Our study allowed us to identify parts of the region (suitable candidate cells) where the installation of artificial nest sites might be particularly desirable considering both habitat suitability and modelled (un)availability of natural nest-sites. Interestingly, the number of 1 x I km cells suitable for both species depicted a potential owl range of $725 \mathrm{~km}^{2}$ (after excluding two cells outside its geographical range) when using the single-run model, and $852 \mathrm{~km}^{2}$ (after excluding three cells outside the geographical range of the species) when using the average output provided by the 10-replicates model. The average owl density in suitable landscapes in our study region and neighbouring areas is around 0.5 pairs $/ \mathrm{km}^{2}$ (Gustin et al. 2009), so we estimate a population of c.360-430 pairs, a figure which falls well within the regional estimate of the Boreal Owl population (250-500 pairs). This perhaps suggests that current owl distribution coincides with the simultaneous occurrence of suitable habitat and Black Woodpecker, as hypothesised at the beginning of our work, and is limited by the availability of suitable nest-holes; the same pattern was suggested for the neighbouring Trento province 


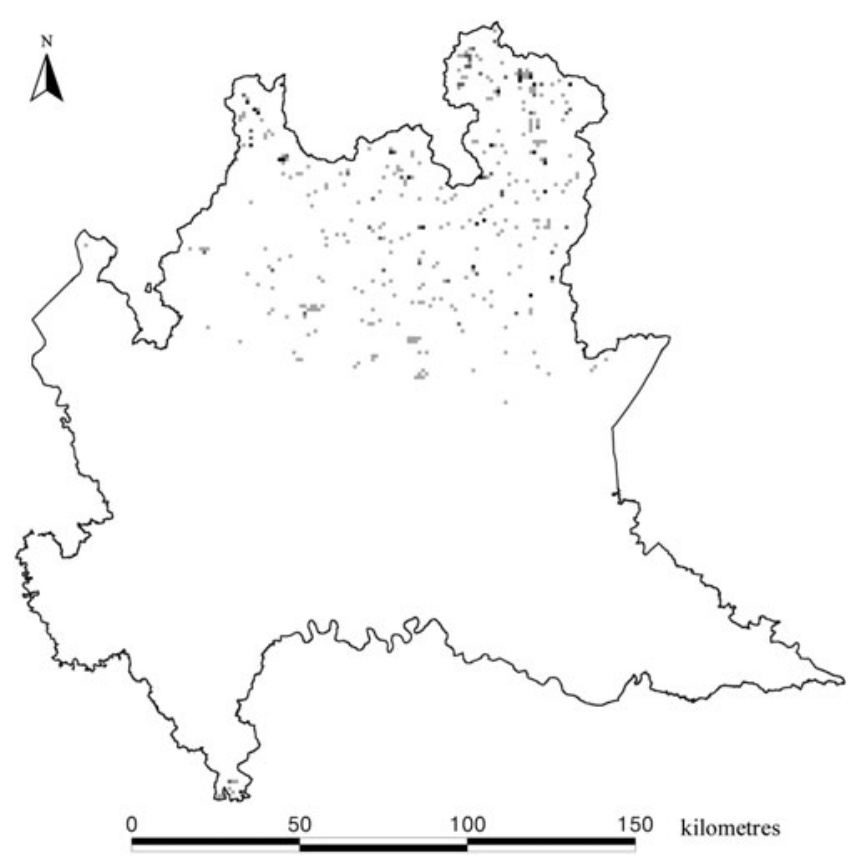

Figure 3. Candidate cells: these sites should be considered as the most suited for nest-box provisioning for Boreal Owl, as they include areas suitable for the owl (the darkest the colour, the highest the occurrence probability), whereas Black Woodpecker occurrence (and hence natural nestsites availability) is unlikely. Although habitat structure and elevation of a very few cells in the Apennines (southern corner) are compatible with species ecological requirements, these cells have been excluded because they are outside the range of the species.

(Pedrini et al. 2005). This means that potentially the use of nest-boxes could significantly increase the regional population of Boreal Owl. This species may also occupy forest habitats at higher elevation than Black Woodpecker (López et al. 2010), and many of the candidate cells are located above the altitudinal limit usually reached by Black Woodpecker in Lombardy. The sample of candidate cells could be easily converted into a georeferenced list of sites which should be visited and assessed before installation of nest-boxes, to check for possible factors not considered by modelling (e.g. presence of disturbance, competitors, recently changed land cover, etc.). Expert opinion could thus be used to integrate the assessment (driven by models at the regional level) at the local scale. Priority should be given to highly suitable cells within the main range of the species in Lombardy, i.e. true Alps and northern pre-Alps (Fig. 3), to increase owl abundance in the most suitable part of the region. We were unable to test the true effectiveness of the method we propose for selecting sites for nest-box provision. Such a test would require nest-boxes to be installed in suitable and unsuitable areas, according to the model, and with and without Black Woodpecker. However, we believe that identifying suitable areas where nest holes are likely to be absent, could be useful. In our study area, four nest-boxes were placed in the pre-Alps, in a high-elevation forest area potentially suitable for Boreal Owl (in a $7-\mathrm{km}^{2}$ mountainside including three $1 \mathrm{xI} \mathrm{km}$ cells suitable for the owl), and all were occupied by the species within only three years. In other parts of the Italian Alps, nest-box provision in two rather close areas resulted in high occupation rates at both sites, but with different breeding success: fairly good performance in one population (Mezzavilla and Lombardo 1997) and a high failure rate in the other (Brichetti and Fracasso 2006). This contrasting pattern could indirectly indicate that habitat suitability can be really important in determining 
breeding success in box-nesting Boreal Owls; the use of fine-scale, regional models may help to identify high-quality areas (Brambilla and Ficetola 2012) and the monitoring of breeding success of box-nesting pairs may help to identity factors affecting habitat quality. Our approach could be used to model the potential opportunity for nest-boxes in other species or species pairs. In general, this kind of procedure can be used to infer the need for particular management options when both limiting factors and species distribution can be spatially modelled, and also to model the areas where different target species are more likely to overlap and interact. In our study, the results of distribution modelling may also be used to identify the areas most important for species monitoring, considering the unlikely occurrence of Boreal Owl in areas without woodpeckers.

Sites suitable for both species should also qualify as priority areas for conservation of forest biodiversity, as both Boreal Owl (Sergio et al. 2005) and Black Woodpecker (Pirovano et al. 2003) have been reported as biodiversity indicators in the Italian Alps. Presence-only models are becoming increasingly used in many practical conservation contexts, as they are suited to use data which do not need absence points, provide reliable results, and can be obtained quite easily. Their increasing use as tools to address practical conservation tasks (as in our examples with monitoring, identification of priority areas for forest biodiversity, and nest-box provision) should be encouraged in order to accomplish practical tasks according to sound knowledge and a robust basis, instead of using expert judgement or practical constraints as unique criteria.

\section{Supplementary Material}

The online supplementary materials for this article can be found at journals.cambridge.org/bci

\section{Acknowledgements}

Funding for this work to Fondazione Lombardia per l'Ambiente (FLA) was provided by Lombardy Region (DG Sistemi Verdi e Paesaggio) within the project "Piano di monitoraggio dei Vertebrati terrestri di interesse comunitario in Lombardia". We are very grateful to S. Colaone, W. Guenzani, A. Madella, A. Mazzoleni, N. Semperboni, M. Tomasi, R. Tomasini and T. Zarbo for help with fieldwork, and to F. Huettmann, T. Wesołowski and an anonymous reviewer for comments and criticisms on a first draft.

\section{References}

Araújo, M. B. and Williams, P. H. (200o) Selecting areas for species persistence using occurrence data. Biol. Conserv. 96: 331-345.

Bartel, R. A. and Sexton, J. O. (2009) Monitoring habitat dynamics for rare and endangered species using satellite images and niche-based models. Ecography 32: 888-896.

Bocca, M., Carisio, L. and Rolando, A. (2007) Habitat use, home ranges and census techniques in the Black Woodpecker Dryocopus martius in the Alps. Ardea 95: 17-29.

Both, C., Bouwhuis, S., Lessells, C. M. and Visser, M. E. (2006) Climate change and population declines in a long-distance migratory bird. Nature 441: 81-83.

Bourg, N. A., McShea, W. J. and Gill, D. E. (2005) Putting a CART before the search:
Successful habitat prediction for a rare forest herb. Ecology 86: 2793-2804.

Brambilla, M. and Ficetola, G. F. (2012) Species distribution models as a tool to estimate reproductive parameters: a case study with a passerine bird species. J. Anim. Ecol. 81: $781-787$.

Brambilla, M., Casale, F., Bergero, V., Bogliani, G., Crovetto, G. M., Falco, R., Roati, M. and Negri, I. (2010) Glorious past, uncertain present, bad future? Assessing effects of land-use changes on habitat suitability for a threatened farmland bird species. Biol. Conserv. 143: 2770-2778.

Brambilla, M., Casale, F., Bergero, V., Crovetto, G. M., Falco, R., Negri, I., Siccardi, P. and Bogliani, G. (2009) 
GIS-models work well, but are not enough: Habitat preferences of Lanius collurio at multiple levels and conservation implications. Biol. Conserv. 142: 2033-2042.

Brambilla, M., Falco, R. and Negri, I. (2012) A spatially explicit assessment of withinseason changes in environmental suitability for farmland birds along an altitudinal gradient. Anim. Conserv. 15: 638-647.

Brichetti, P. and Fracasso, G. (2006) Ornitologia Italiana Vol. III. Ozzano dell'Emilia (BO): Alberto Perdisa Editore.

Cramp, S. (1985) The birds of the Western Palearctic, Volume IV. Oxford: Oxford University Press.

Drew, C. A., Wiersma, Y. F. and Huettman, F., eds. (2011) Predictive modeling in landscape ecology. New York: Springer.

Elith, J., Graham, C. H., Anderson, R. P., Dudık, M., Ferrier, S., Guisan, A., Hijmans, R. J., Huettmann, F., Leathwick, J. R., Lehmann, A., Li, J., Lohmann, L. G., Loiselle, B. A., Manion, G., Moritz, C., Nakamura, M., Nakazawa, Y., Overton, J. M., Peterson, A. T., Phillips, S. J., Richardson, K. S., Scachetti-Pereira, R., Schapire, R. E., Soberon, J., Williams, S., Wisz, M. S. and Zimmermann, N. E. (2006) Novel methods improve prediction of species' distributions from occurrence data. Ecography 29: 129-151.

Elith, J., Phillips, S. J., Hastie, T., Dudık, M., Chee, Y. E. and Yates, C. J. (2011) A statistical explanation of MaxEnt for ecologists. Divers. Distrib. 17: 43-57.

Ferrier, S., Watson, G., Pearce, J. and Drielsma, M. (2002) Extended statistical approaches to modelling spatial pattern in biodiversity in northeast New South Wales. I. Specieslevel modelling. Biodivers. Conserv. I1: 2275-2307.

Fouquet, A., Ficetola, G. F., Haigh, A. and Gemmell, N. (2010) Using ecological niche modelling to infer past, present and future environmental suitability for Leiopelma hochstetteri, an endangered New Zealand native frog. Biol. Conserv. 143: 1375-1384.

Graham, C. H., Ferrier, S., Huettman, F., Moritz, C. and Peterson, A. T. (2004) New developments in museum-based informatics and applications in biodi- versity analysis. Trends Ecol. Evol. 19: 497-503.

Gustin, M., Brambilla, M. and Celada, C. (2009) Valutazione dello stato di conservazione dell'avifauna italiana. Roma: Ministero dell'Ambiente, della Tutela del Territorio e del Mare \& LIPU/BirdLife Italia.

Jiménez-Valverde, A., Lobo, J. M. and Hortal, J. (2008) Not as good as they seem: the importance of concepts in species distribution modelling. Divers. Distrib. 14: 885-890.

Klein, Á., Nagy, T., Csörg, T. and Mátics, R. (2007) Exterior nestboxes may negatively affect Barn Owl Tyto alba survival: an ecological trap. Bird Conserv. Internatn. 17: 273-281.

Korpimaki, E. (1985) Clutch size and breeding success in relation to nest-box size in Tengmalm's owl Aegolius funereus. Holarctic Ecol. 8: 175-180.

Lawler, J. J., Wiersma, Y. F. and Huettmann, F. (2010) Designing predictive models for increased utility: using species distribution models for conservation planning, forecasting, and risk assessment. In C. A. Ashton, Y. Wiersma and F. Huettman, eds. Predictive modeling in landscape ecology. New York: Springer.

López, B. C., Potrony, D., López, A., Badosa, E., Bonada, A. and Saló, R. (2010) Nest-box use by Boreal Owls (Aegolius funereus) in the Pyrenees Mountains in Spain. J. Raptor Res. 44: 40-49.

Mänd, R., Tilgar, V., Lõhmus, A. and Leivits, A. (2005) Providing nest boxes for hole-nesting birds - does habitat matter? Biodivers. Conserv. 14: 1823-1840.

Mezzavilla, F. and Lombardo, S. (1997) Biologia riproduttiva della civetta capogrosso (Aegolius funereus) nel bosco del Cansiglio. Fauna 4: IOI-114.

Møller, A. P. (1989) Parasites, predators and nest boxes: Facts and artefacts in nest box studies of birds. Oikos: 421-423.

Newton, I. (1994) Experiments on the limitation of bird breeding densities: a review. Ibis 136 : 397-411.

Pedrini, P., Caldonazzi, M. and Zanghellini, S., eds. (2005) Atlante degli uccelli nidificanti e svernanti in provincia di Trento. Trento: Museo Tridentino di Scienze Naturali.

Peterson, A. T., Soberón, J. and SánchezCordero, V. (1999) Conservatism of 
ecological niches in evolutionary time. Science 285: 1265-1267.

Phillips, S. J., Anderson, R. P. and Schapire, R. E. (2006) Maximum entropy modeling of species geographic distributions. Ecol. Model. 190: 231-259.

Pirovano, A., Zecca, G. and Guidali, F. (2003) Il picchio nero Dryocopus martius quale indicatore di biodiversità forestale nel Parco regionale delle Orobie Valtellinesi. Avocetta 115: 27.

Postma, E. and van Noordwijk, A. J. (2005) Gene flow maintains a large genetic difference in clutch size at a small spatial scale. Nature 433: 65-68.

Raxworthy, C. J., Martinez-Meyer, E., Horning, N., Nussbaum, R. A., Schneider, G. E., Ortega-Huerta, M. A. and Peterson, A. T. (2003) Predicting distributions of known and unknown reptile species in Madagascar. Nature 426 : 837-841.

Sergio, F., Newton, I. and Marchesi, L. (2005) Top predators and biodiversity. Nature 436: 192.
Thuiller, W., Lavorel, S., Araujo, M. B., Sykes, M. T. and Prentice, I. C. (2005) Climate change threats to plant diversity in Europe. Proc. Natl. Acad. Sci. USA 102: 8245-8250.

VanDerWal, J., Shoo, L. P., Johnson, C. N. and Williams, S. E. (2009) Abundance and the environmental niche: Environmental suitability estimated from niche models predicts the upper limit of local abundance. Am. Nat. 174: 282-291.

Veen, T., Borge, T., Griffith, S. C., Sætre, G.-P., Buresk, S., Gustafsson, L. and Sheldon, B. C. (2001) Hybridization and adaptive mate choice in flycatcher. Nature 411: 45-50.

Virkkala, R. (2006) Why study woodpeckers? The significance of woodpeckers in forest ecosystems. Ann. Zool. Fenn. 43: 82-85.

Wesołowski, T. (2007) Lessons from long-term hole-nester studies in a primeval temperate forest. J. Ornithol. 148 suppl. 2: 395-405.

Zingg, S., Arlettaz, R. and Schaub, M. (2010) Nestbox design influences territory occupancy and reproduction in a declining, secondary cavity-breeding bird. Ardea 98: 67-75.

\section{MATTIA BRAMBILLA ${ }^{* 1,2}$, ENRICO BASSI ${ }^{1}$, VALENTINA BERGERO ${ }^{1}$, FABIO CASALE ${ }^{1}$, MARCO CHEMOLLO ${ }^{1}$, RICCARDO FALCO ${ }^{1}$, VIOLETTA LONGONI ${ }^{\prime}$, SEVERINO VITULANO ${ }^{1,3}$ \\ ${ }^{1}$ Fondazione Lombardia per l'Ambiente, Settore Biodiversità e Aree protette, Largo to luglio 1976 1, I-20822 Seveso (MB), Italy. \\ ${ }^{2}$ also Museo delle Scienze, Sezione Zoologia dei Vertebrati, Via Calepina 14, I-38122 Trento, Italy. \\ ${ }^{3}$ also Associazione FaunaViva, Viale Sarca 78, I-20125 Milano, Italy.}

\section{FABIO SAPORETTI}

Gruppo Insubrico di Ornitologia Onlus, clo Civico Museo Insubrico di Storia Naturale di Clivio e Induno Olona, Via Manzoni 21, 21050 Clivio (VA), Italy.

\section{ENRICO VIGANÒ}

Nucleo faunistico, Polizia provinciale di Lecco, Corso Matteotti 3, I-2390o Lecco, Italy.

${ }^{*}$ Author for correspondence; email: brambilla.mattia@gmail.com

Received 13 October 2011; revision accepted 4 September 2012; Published online 9 April 2013 